\title{
ASO Visual Abstract: How to Safely Perform Repeat Sentinel Node Biopsy After a Previous Mastectomy-Technical Features and Oncological Outcomes
}

Elisa Vicini, $\mathrm{MD}^{\mathbf{1}}$, Maria Cristina Leonardi, $\mathrm{MD}^{\mathbf{2}}$, Sabrina Kahler Ribeiro Fontana, MD, $\mathrm{PhD}^{\mathbf{1}}$, Eleonora Pagan, $\mathrm{PhD}^{3}$, Vincenzo Bagnardi, $\mathrm{PhD}^{3}$, Laura Gilardi, $\mathrm{MD}^{4}$, Anna Cardillo, $\mathrm{MD}^{5}$, Paola Rafaniello Raviele, MD ${ }^{6}$, Manuela Sargenti, $\mathrm{MD}^{1}$, Consuelo Morigi, $\mathrm{MD}^{1}$, Mattia Intra, MD, $\mathrm{PhD}^{1}$, Paolo Veronesi, MD, $\mathrm{PhD}^{1,7}$, and Viviana Galimberti, $\mathrm{MD}^{1}$

${ }^{1}$ Division of Breast Surgery, European Institute of Oncology IRCCS, Milan, Italy; ${ }^{2}$ Division of Radiation Oncology, European Institute of Oncology, IRCCS, Milan, Italy; ${ }^{3}$ Department of Statistics and Quantitative Methods, University of Milan-Bicocca, Milan, Italy; ${ }^{4}$ Division of Nuclear Medicine, European Institute of Oncology, IRCCS, Milan, Italy; ${ }^{5}$ Division of Medical Senology, European Institute of Oncology, IRCCS, Milan, Italy; ${ }^{6}$ Division of Pathology, IEO, European Institute of Oncology IRCCS, Milan, Italy; ${ }^{7}$ Department of Oncology and Hematology-Oncology, University of Milan, Milan, Italy

Repeat sentinel node biopsy after mastectomy is a nonstandard procedure. This practice can represent a safe option to detect and remove occult axillary disease in order to achieve better local control and could influence the choice of adjuvant treatment (https://doi.org/10.1245/s104 34-021-10986-z).

\section{How to Safely Perform Repeat Sentinel Node Biopsy After a Previous Mastectomy: Technical Features and Oncological Outcomes}

\begin{tabular}{|c|c|c|c|}
\hline Background & Methods & Results & Conclusions \\
\hline $\begin{array}{l}\text { The latest NCCN Breast } \\
\text { Cancer Guidelines still } \\
\text { discourage repeat sentinel } \\
\text { node biopsy after mastectomy }\end{array}$ & $\begin{array}{l}\text { - } 89 \text { patients with local } \\
\text { recurrence of breast cancer } \\
\text { after mastectomy } \\
\text { - No distant metastases } \\
\text { - Clinically and ultrasound } \\
\text { negative axilla } \\
\text { - No previous axillary dissection }\end{array}$ & $\begin{array}{l}\text { - } 99 \% \text { successful sentinel } \\
\text { node biopsy } \\
\text { - } 14 \% \text { metastatic sentinel node } \\
\cdot 82 \% \text { additional axillary nodes } \\
\text { involved after a positive } \\
\text { sentinel node } \\
\text { - } 96.7 \% \text { Overall survival } \\
\cdot 84.4 \% \text { Disease-free survival } \\
\text { - No axillary relapse after } \\
\text { axillary dissection }\end{array}$ & $\begin{array}{l}\text { Repeat axillary sentinel node } \\
\text { biopsy after mastectomy can } \\
\text { represent a safe option to } \\
\text { detect and remove occult } \\
\text { axillary disease which would } \\
\text { otherwise not be excised/ } \\
\text { irradiated in order to achieve } \\
\text { better local control and could } \\
\text { possibly influence the choice } \\
\text { of adjuvant treatments }\end{array}$ \\
\hline $\begin{array}{l}\text { Vicin } \\
\text { Visual }\end{array}$ & & & $\begin{array}{l}\text { ANNALS OF } \\
\text { SURGICAL } \\
\text { ONCOLOGY }\end{array}$ \\
\hline
\end{tabular}

(C) Society of Surgical Oncology 2021

Published Online: 26 November 2021

E. Vicini, MD

e-mail: elisa.vicini@hotmail.it
Publisher's Note Springer Nature remains neutral with regard to jurisdictional claims in published maps and institutional affiliations. 